\title{
ENGLISH TEACHERS' PROBLEMS IN APPLYING THE 2013 CURRICULUM
}

\author{
Yulia Nur Ekawati \\ Department of English Education, Faculty of Teacher Training and Educaiton, University of \\ Pancasakti Tegal \\ E-mail: yulianurekawati.ups@gmail.com
}

APA Citation: Ekawati, Y. N. (2017). English teachers' problems in applying the 2013 curriculum. English Review: Journal of English Education, 6(1), 41-48. DOI: 10.25134/erjee.v6i1.769.

Received: 19-08-2017

Accepted: $25-10-2017$

Published: 01-12-2017

\begin{abstract}
The 2013 curriculum is regarded as the current issue for teachers and students. This curriculum is based on the competencies concerning on implementing four aspects of spiritual, attitude, knowledge and skills in order to achieve students' character building. This study, moreover, investigates the teachers' problems in applying the 2013 curriculum at vocational high school in Tegal. Four English teachers are observed and interviewed to obtain data. The data is analyzed referring to four points; a) preparing lesson plan, b) applying the steps of teaching learning activities, c) preparing media, and d) making evaluation. The result shows that; a) three teachers do not prepare lesson plan before their teaching learning process, b) for all teachers, they understand the principles of scientific approach and the basic concept of 2013 curriculum (i.e. inquiry-based learning, project-based learning, discovery-learning, problem-based learning and task-based learning) but they do not apply it in their teaching, c) one teacher prepares the teaching media but the others do not prepare it, and d) all teachers get difficulties in assessing students' attitude (behaviour).
\end{abstract}

Keywords: English teachers' problem, the 2013 curriculum

\section{INTRODUCTION}

The curricula of Indonesia have been developed since 1947 until 2013 (Widodo, 2015). The development of curriculum is regarded as the changing of people need, technology, thinking, as well as market challenges. In 2004, the curriculum of Indonesia is called as CBC (CompetenceBased Curriculum), which is implemented to be pioneer of applying curriculum based on the competences. Honestly, it only works for two years. Furthermore, in 2006, the curriculum changes to ULEC (Unit Level of Education Curriculum), which is the development of the previous curriculum. The changing of curriculum is, moreover, continued in 2013 which is named as the 2013 curriculum.

In Indonesia, the 2013 curriculum is the newest curriculum focusing on achieving students' competencies and character building (Kementrian dan Kebudayaan,
2013). There are four aspects of competences expected to be achieved; spiritual, attitude, knowledge and skills which are then stated in the Core Competences (Kompetensi Inti/KI). Those aspects are stated in the purpose of national education (Pasal 3 UU No 20 Sisdiknas 2003) stating that "To develop students' potential to become faithful and pious man, noble, healthy, knowledgeable, skilled, creative, independent, and also to become democratic and responsible citizen."

From the purpose stated above, it is clear that the spiritual attitude is shown as faithful and pious man. The social attitude, then, is shown in the terms of healthy, independent, democratic and responsible. Furthermore, for the aspect of knowledge is mentioned in knowledge and the aspect of skill is shown in skilled and creative. Through those aspects, it can be concluded 
that the purpose of standard competence in achieving attitude (spiritual and social) means to create students who are faithful, noble, confident, and responsible in interacting with social environment. Next aspect is skill which aims to make person capable to think and follow productively and creatively in abstract and concrete field. Further, the last aspect is knowledge. It purposes to create students who master science, technology, arts, culture and humanity, nationality, state insights, and civilization.

Dealing with the above ideal and perfect purposes, it comes several issues in implementing the 2013 curriculum in English Language Teaching (ELT) practices. Sahirudin (2013) reviews the history of ELT in Indonesia. The central government determined that English became the first foreign language obligated to be taught at junior and senior high school since independency in 1945. Indonesia curricula have changed for several times. He explained as following:

(a) 1945 was grammar translation-based curriculum.

(b) 1958 was audio-lingual basedcurriculum.

(c) 1975 was revised audio-lingual based-curriculum.

(d) 1984 was structure-based communicative curriculum.

(e) 1994 was meaning-based communicative curriculum.

(f) 2004 was competency-based curriculum.

(g)2006 was KTSP curriculum.

(h) 2013 was the 2013 curriculum.

Those curricula have each strengths and weaknesses (constraints). Its constraints make the government to rethink, reformulate, and redesign the curriculum to be implemented.

In this research, Sahirudin (2013) moreover investigates the common problems faced by the implementation of 2013 curriculum. They are students' lack of motivation, poor attitude toward language learning, big class size, unqualified teachers, and cultural barriers for teachers to adopt new role of facilitators. In the context of ELT, the reduction of allocating time for English subject at school as well becomes the problem. These issues then make several consequences for language teaching and learning process in Indonesia. However, there are some certain resources to the development of the quality in ELT, i.e. the policy of teacher's certification program, the integrative topic in some subjects and textbook provision.

Another previous research was held by Retnawati, et al. (2016). They investigated the vocational high school teachers' difficulties in applying the assessment within 2013 curriculum. This research was descriptive explorative using qualitative data gathering. The data sources were 22 vocational high school teachers and the vice Principals of curriculum in the province of Yogyakarta Special Region of Indonesia. The result showed that the teachers' difficulties in implementing 2013 curriculum were found in; developing the instrument of attitude, implementing the authentic assessment, formulating the indicators, designing the assessment rubric for skills, and gathering the scores from multiple measurement techniques. In addition, this study stated that it was difficult to find feasible application for describing students' achievement.

Based on the previous studies, teachers (especially English teachers) should comprehend the characteristics of 2013 curriculum. The curriculum of 2013 is designed with characteristics of developing a balance between spiritual and social attitudes, knowledge and skills which should be applied in various situations in the school and community (Permendikbud No. 59 Tahun 2014). It becomes the basic understanding for teachers in their teaching so that the objectives of this curriculum are achieved. In addition, syllabus and lesson plan must be prepared effectively before teaching learning process, as it will be a teacher's guide. 
The syllabus has been prepared by team of curriculum developers; in central and regional levels, and teachers only develop the lesson plan based on teacher's guide book and resource (Permendikbud No.59 Tahun 2014). Another teaching preparation supporting the teaching learning process is the use of media. In this curriculum, the role of media is very significant, since it can make the teaching activities more creative and interesting. So, the teacher should use the appropriate teaching method. In applying the 2013 curriculum, moreover, Scientific Approach must be clearly understood by teachers. This approach contains the steps of teaching and learning process including observing, questioning, associating, experimenting and networking. It is called a natural assessment as well meaning that the teacher not only assesses the cognitive development of the students, but also assesses the psychometrics and affective aspects (attitude).

I perceive that the implementation of 2013 curriculum should be understood by all teachers as it is a must from government to be implemented currently. However, it is found there are some issues faced by teachers in applying this curriculum. This research, therefore, concerns on evaluating the teacher's problems in applying the 2013 curriculum. The problems are investigated based on four aspects i.e. a) preparing lesson plan, b) applying the steps of teaching learning activities based on Scientific Approach, c) preparing media, and d) making evaluation.

\section{METHOD}

This research used qualitative method. There are 7 state vocational high schools and 31 private vocational high schools in Tegal District. In this study, the researcher only took four English teachers as the participants from four different private vocational high schools using purposive sampling technique. This technique is taken based on the researcher consideration and aim. The result of this study will not be generalized to population (all schools) since the concept of qualitative method is only applied in this social situation case and can be transferred to other social situation (Sugiyono, 2013, p. 216).

To collect the data, the researcher used Triangulation technique combining observation and interview. This technique, as stated by Stainback (1988) in Sugiyono (2013, p. 241), has aim not to determine the truth about some social phenomenon, rather the purpose of triangulation is to increase one's understanding of whatever is being investigated. It means that triangulation aims to increase researcher understanding about social phenomenon and investigate whether the information getting from informant/ participant is wrong as it is not appropriate with theory and law.

Figure 1. Data Analysis (Interactive Mode)

(Miles \& Huberman, 1984) as cited in (Sugiyono, 2013, p. 247)

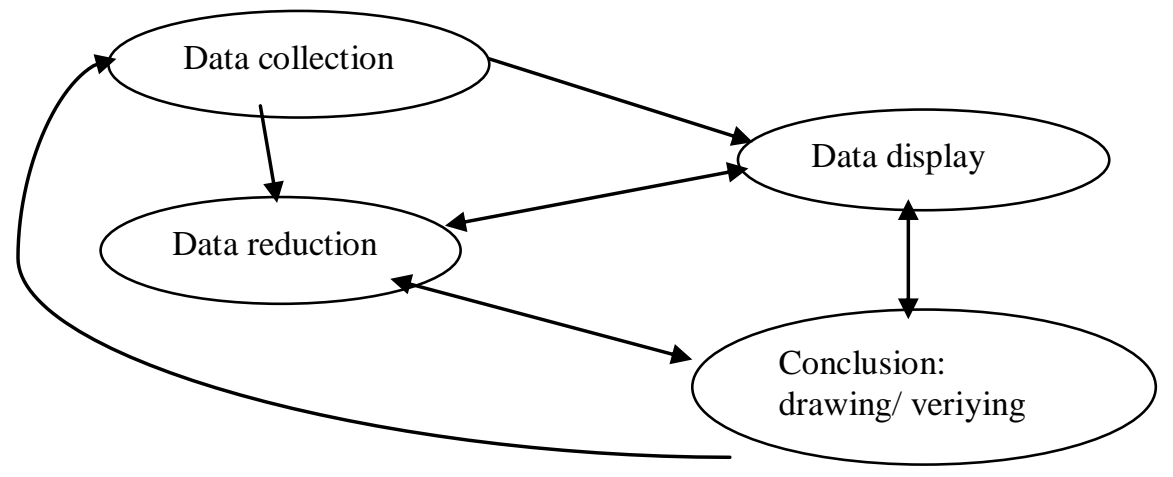

The questions of interview, moreover, are mentioned in Table 1. 
Table 1. Questions of interview

\begin{tabular}{ccc}
\hline NO. & Questions & Answer \\
\hline 1. & Do you agree that preparing lesson plan is important? & Yes/No \\
\hline 2. & Do you arrange the objectives of learning? & Yes/No \\
\hline 3. & Do you arrange the material based on objectives of learning? & Yes/No \\
\hline 4. & Do you arrange the learning activities based on scientific approach? & Yes/No \\
\hline 5. & Do you apply all steps on scientific approach? & Yes/No \\
\hline 6. & Are your students interested on your teaching? & Yes/No \\
\hline 7. & Are your students active asking questions in classroom? & Yes/No \\
\hline 8. & Do you prepare media of teaching and learning? & Yes/No \\
\hline 9. & Do you use pictures? & Yes/No \\
\hline 10. & Do you use media of power point, video, LCD or internet? & Yes/No \\
\hline 11. & Do you use government book? & Yes/No \\
\hline 12. & Do you arrange evaluation based on objectives of lesson? & Yes/No \\
\hline 13. & Do you measure those four aspects in 2013 curriculum (spiritual, social, & Yes/No \\
\hline
\end{tabular}

Points 1 to 3 are categorized in the aspect of preparing lesson plan. While in points 4 to 7 are included in applying the steps of learning activities (scientific approach). The aspect preparing media is shown in points 8 to 11 . Lastly, for aspect of making evaluation is stated in points 12 to 13.

After the data was collected, the next step is analyzing the data. The technique to analyze the data is drawn in Figure 1. Based on the picture, to analyze data, there are several activities done i.e.: data reduction, data display, and conclusion. After collecting the data, the next step done is reducing the data by summarizing, choosing the important point, categorizing the data, making symbol and finding the theme and pattern.

\section{RESULTS AND DISCUSSION}

The research showed that English teachers in four private vocational high schools in Tegal have some problems in implementing the 2013 curriculum. The problems are influenced by the teachers themselves, students, and conditions of school. It is then classified and categorized into four aspects i.e.; a) preparing lesson plan, b) applying the steps of teaching learning activities, c) preparing media, and d) making evaluation. The following explanation describes the result of this research regarding those teachers' problems.

\section{Preparing lesson plan}

All teachers agreed that preparing lesson plan before teaching and learning process is important. They can prepare the objectives and materials of lesson effectively. The materials arranged are based on objectives of learning. Through lesson plan, they are also able to arrange the learning activities systematically based on scientific approach in the 2013 curriculum. Although they were aware on the importance of preparing lesson plan, the result of this study showed that only one English teacher made detail lesson plan before his teaching and learning and the three teachers did not prepare it well.

The first teacher prepared detail lesson plan in every teaching. She arranged one lesson plan for two meetings. The objectives of learning are developed from the goal (basic competences) stated in syllabus. After that, she prepared materials based on objectives of lesson and took the material from government book and some other references from Exercise Book $(L K S)$ and internet. The problems, in addition, came up as the books are less available. She then duplicated by copying the book and students should spend some money to pay it. Another problem came when she decided the method of teaching to combine with scientific approach since the students are quite passive. The students are really shy to speak and regard that English is difficult subject. In preparing lesson plan, the first English 
teacher stated that it is a must for teacher to make a preparation before teaching. The preparation are arranging lesson plan, choosing media which is appropriate to the material, and preparing exercises to measure students' understanding based on material taught.

The second English teacher stated that before his teaching, he did not make detail lesson plan. He just prepared the outline what would be done during the teaching learning process. The reason why he did not made lesson plan is as he taught five classes and each class containing large students of 30 so he did not have a lot of time to make a preparation. He mentioned that preparing lesson plan in 2013 curriculum was so complicated since there was attitude aspect to measure.

Other result was showed by the third participant who explained that she could not prepare lesson plan because she used government book as a guidance to teach. From this book, she could prepare what material should be given to students. As it has been stated the learning objectives based on syllabus, so she just used the book without arranging the lesson plan.

The last participant stated that preparing lesson plan before teaching and learning is important, but he did not prepare it as he needed time to prepare it and he considered that through the guidance of book was good to explain the material. In some cases, he made a note or draft of teaching which mentioned the goals that should be achieved by students, the method of teaching, and the material. He did not arrange the evaluation because he used an exercise book (LKS). In scoring, he got problem because in LKS there is no guidance to give score.
Based on the result above, it can be concluded that the teachers' problem in preparing lesson plan is caused by the teacher's readiness. They stated that no time to prepare detailed lesson plan since it is very complicated. They got difficulty in identifying and arranging learning objective, indicators, material, method of teaching, learning activities and evaluation. However, without detail lesson plan, those teacher used government book as a guidance in their teaching and sometimes they made draft or outline about their teaching planning in general.

The solution of this problem is that teachers need to refresh their teaching competences especially about making lesson plan in any kind of workshop held by teacher team $(M G M P)$ or socialization through Forum Group Discussion (FGD). It is as preparing lesson plan helps teachers to organize the objectives, material, learning activities and evaluation effectively. Moreover, teachers would be more confidence when delivering the lesson. Other benefit is through preparing lesson plan students would be helped to achieve their learning objectives more easily.

\section{Applying the steps of teaching and learning activities (scientific approach)}

To evaluate teachers' problem in applying the steps of teaching and learning activities, the researcher asked the following questions containing teachers' understanding in scientific approach, the implementation of scientific approach, and students' responses. The result of interview can be seen in Table 2.

Table 2. Result interview of applying scientific approach

\begin{tabular}{|c|c|c|c|c|c|}
\hline Questions & Aspect & $1^{\mathrm{st}}$ teacher & $2^{\text {nd }}$ teacher & $\begin{array}{c}3^{\text {rd }} \\
\text { teacher }\end{array}$ & $4^{\text {th }}$ teacher \\
\hline $\begin{array}{l}\text { Do you arrange the } \\
\text { learning activities based on } \\
\text { scientific approach? }\end{array}$ & \multirow{3}{*}{$\begin{array}{l}\text { Applying the } \\
\text { steps of } \\
\text { teaching } \\
\text { learning } \\
\text { activities } \\
\text { (Scientific } \\
\text { Approach) }\end{array}$} & Yes & Yes & No & No \\
\hline $\begin{array}{c}\text { Do you apply all steps of } \\
\text { scientific approach? }\end{array}$ & & $\begin{array}{l}\text { Not all } \\
\text { steps }\end{array}$ & No & No & No \\
\hline $\begin{array}{l}\text { Are your students } \\
\text { interested on your }\end{array}$ & & Yes & Yes & Yes & Yes \\
\hline
\end{tabular}




\begin{tabular}{ccccc}
\hline teaching? & & & \\
\cline { 3 - 5 } $\begin{array}{c}\text { Are your students active } \\
\text { asking questions in } \\
\text { classroom? }\end{array}$ & Not all & No & No & No \\
students & & & \\
\hline
\end{tabular}

Based on the result above, it can be concluded that teachers understand the principles of scientific approach and the basic concept of 2013 curriculum (i.e. inquiry-based learning, project-based learning, discovery-learning, problem-based learning and task-based learning) but in terms of applying this concept, they did not apply it since the students were quite passive in the classroom. They were shy, afraid, and not confidence. They also regarded that English is difficult. Another problem in applying this approach was teachers could not apply students-centered learning since students still depend on their teacher a lot. This is, of course, becoming the challenges for teachers making students to be active. Therefore, teachers and government need to take a consideration for the schools which have low input of competences in order to apply not only limited on scientific approach but also other approaches in order there are various method of teaching.

\section{Preparing media}

In preparing media, the result showed that all teachers used media of pictures in their teaching. They explained that pictures are kind of media which is easy to get and interesting, thus students can understand the material. However, the media of LCD, video, and power point did not used since the limitation of facilities those schools have. The following is the result of teachers' problem in preparing media.

Table 3. Preparing media

\begin{tabular}{|c|c|c|c|c|c|}
\hline Questions & Aspect & $1^{\mathrm{st}}$ teacher & $\begin{array}{c}2^{\text {nd }} \\
\text { teacher }\end{array}$ & $3^{\text {rd }}$ teacher & $4^{\text {th }}$ teacher \\
\hline $\begin{array}{l}\text { Do you prepare media of } \\
\text { teaching and learning? }\end{array}$ & \multirow[t]{4}{*}{$\begin{array}{l}\text { Preparing } \\
\text { media }\end{array}$} & Yes & No & Yes & $\begin{array}{c}\text { Yes } \\
\text { sometimes }\end{array}$ \\
\hline Do you use pictures? & & Yes & Yes & Yes & Yes \\
\hline $\begin{array}{l}\text { Do you use media of } \\
\text { power point, video, LCD } \\
\text { or internet? }\end{array}$ & & $\begin{array}{c}\text { Yes } \\
\text { sometimes }\end{array}$ & No & $\begin{array}{c}\text { Yes } \\
\text { sometimes }\end{array}$ & No \\
\hline $\begin{array}{l}\text { Do you use government } \\
\text { book? }\end{array}$ & & Yes & Yes & Yes & Yes \\
\hline
\end{tabular}

From the table above, the first and third teachers prepared media before their teaching. With the problem in facilities, they tried to use media such as pictures and video. They sometimes used LCD because it was not provided in every class. Other teachers also prepared media of picture in their teaching. This is therefore needed a solution by stakeholders (school and government) to provide additional budget in supporting school facilities especially in applying this curriculum. The limitation of government books also becomes the problem. To overcome this problem, students should copy the book. Therefore, it would be attention for many stakeholders.

\section{Making evaluation}

There are four main aspects of competences to be implemented in 2013 curriculum i.e. spiritual, social, knowledge and skill aspects. Those aspects are stated in the core and basic competences (Permendikbud No.59 Tahun 2014). It is therefore to be developed in teaching learning indicators and objectives. Teachers would know the students' understanding if they can achieve the indicator and objectives of teaching learning through evaluation. In evaluation, it contained the indicators of evaluation, technique and form of evaluation as well as the rubric or scoring. 
The result showed that all teachers got difficulties in arranging evaluation. It needed long time to input the score of four aspects since the class is quite large. They also got the problem in making an individual assessment or pair assessment and affective assessment. In giving pair assessment, the students sometimes are not honest about their marks. While in affective assessment, it is difficult for teacher to analyze and evaluate the attitude of every student in his class. Moreover, teachers regarded that this curriculum is too complex in which teacher needed to evaluate students' attitude (through observation), students' knowledge (through test), and students' skill (through practice).

This problem is due to teachers' lack understanding in giving evaluation. To overcome teachers' problem in making evaluation, thus, teachers should get adequate socialization and workshop which should be guided by competent instructor. They also should be trained to prepare appropriate instrument for evaluation. In addition, it is needed to be considered by government and stakeholder to provide easy software of evaluation to help teachers in reporting the result of evaluation.

\section{CONCLUSION}

The implementation of 2013 curriculum faces some problems in four English teachers of private vocational high schools in Tegal during preparing lesson, applying steps of learning activities (scientific approach), preparing media, and making evaluation. They stated that preparing lesson plan before teaching and learning process is important but it was hard to do since the limited time to make preparation. Through lesson plan, the objectives of lesson and material could be delivered systematically and will help students to achieve its objectives. In fact, they had problem in preparing lesson plan due to limited time to make detail lesson plan. Moreover, the problem happened when teachers applied the steps of scientific approach. The students were passive in the classroom. They also regarded English as a difficult subject to learn. Media as a tool to support the material is provided in limited items, it is as the facilities in those schools are not supported well. To evaluate the students' understanding, teachers also found problems. It seemed difficult to measure something abstract like the aspects of spiritual and attitude. In addition, they also got difficulty in giving score when observing students attitude and speaking skill because it needed a lot of time. In line with those problems faced by teachers, therefore, the solution should be taken by government and stakeholders such as providing deeper socialization and workshop to increase teachers' understanding in implementing 2013 curriculum especially for all private English teachers of vocational high school who never had been given the socialization and training relating to the new curriculum.

\section{REFERENCES}

Kementrian dan Kebudayaan. (2013). Modul pelatihan implementasi kurikulum 2013. Badan pengembangan sumber daya manusia pendidikan dan kebudayaan dan penjaminan mutu pendidikan.

Retnawati, et al. (2016). Vocational high school teachers' difficulties in implementing the assessment in curriculum 2013 in Yogyakarta Province of Indonesia. International Journal of Instruction January, 9(1). Retrieved from www.e-iji.net.

Sahirudin. (2013). The implementation of the 2013 curriculum and the issues of English language teaching and learning in Indonesia. The Asian Conference on Language Learning 2013, Official Conference Proceeding.

Widodo. (2015). Newest issues for curriculum reform in Indonesia (2013). Presented at APEC-

Tsukuba International Conference University of Tsukuba Tokyo Japan. 
Yulia Nur Ekawati

English teachers' problems in applying the 2013 curriculum 